\title{
Pyrrhonian Language
}

\author{
Andrea Lozano-Vásquez \\ Universidad de los Andes (Uniandes) \\ a.lozano72@uniandes.edu.co
}

\begin{abstract}
This article characterises how the Pyrrhonian Sceptic uses language to test if such use is susceptible to Dogmatic criticisms, especially from a Stoic perspective. It will examine two characterisations of that use. The first one, reported by Diogenes Laertius in his Lives of Eminent Philosophers 9.71-78, will be discussed as a logical use of human language broader than a philosophical one. The second characterisation depends on the discourse chosen by Timon of Phlius in his Silloi. In this work, the Epic catalogue shows itself as a powerful mechanism; it allows to report, to make history about philosophy itself and to offer an account of Pyrrho's place in it without postulating substantive theses. This literary use and the previous philosophical one constitute the particular uses of Pyrrhonian language.
\end{abstract}

Keywords: Pyrrhonism, Diogenes Laertius, Timon of Phlius, epic catalogues, history.

\section{La lengua de los pirrónicos}

RESUMEN: Este artículo caracteriza el uso del lenguaje del escéptico pirrónico con el ánimo de examinar si tal uso es susceptible de las críticas dogmáticas, especialmente de las estoicas. Se examinarán dos caracterizaciones de ese uso. La primera, presente en el testimonio de Diógenes Laercio en sus Vidas de filósofos ilustres 9.71-78, evidenciará un uso del lenguaje humano cuyas estrategias permiten un empleo filosófico más amplio que el asertórico. La segunda caracterización se deriva del registro elegido por Timón de Fliunte en sus Silloi. En esta obra, el catálogo épico se muestra como un poderoso mecanismo que permite informar, hacer historia de la filosofía y reportar el lugar de Pirrón en ella sin postular tesis sustantivas. Estos usos, filosófico y literario, constituyen los usos particulares del lenguaje pirrónico.

Palabras clave: Pirronismo, Diógenes Laercio, Timón de Fliunte, catálogo épico, historia. 


\section{Introduction ${ }^{1}$}

Language and the understanding of its functioning are unsettling aspects of Scepticism. Besides the apraxia objection, the aphasia challenge is a warhorse deployed against the Sceptics by the Dogmatists, especially by the Stoics. Contrary to the accusation of inactivity that occupies a significant part of contemporary scholarship, this challenge has not been sufficiently worked to characterise the discourse that the Sceptic can use without having to commit to philosophically robust theses. ${ }^{2}$

Lorenzo Corti (2009) deals with apraxia objection. In short, he argues that, despite traditional objections, the Sextan sceptic can act, speak, and understand without entertaining beliefs. This interpretation is quite helpful for some scholars since it is compatible with a rustic reading of Sextan Pyrrhonism. Since the passages in Sextus do not explain this clearly, Corti uses contemporary theories and concepts to defend his thesis and to characterise the speech acts of a radical Sceptic. ${ }^{3}$ Within this conceptual framework and to complete the characterisation of the Sceptic's peculiar use of language, Corti once again (2015) studies DL 9.7477. This passage is dedicated to the Pyrrhonian language, about which is understood as opposing discourse to discourse. ${ }^{4}$ This kind of use seems to be complementary to human language, which is malleable, full of senses and

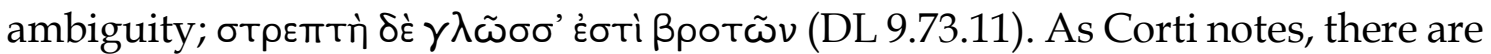
few studies on the peculiarities of Diogenes Laertius' presentation on the status of Sceptical discourse; most studies involve the corresponding passages in Sextus Empiricus (P. 1.187-208), which offer much more detail.

\footnotetext{
${ }^{1}$ This article was part of the Scriptorium project, sponsored by Centro de Investigación y Creación and Vicerrectoría de Investigaciones at Universidad de los Andes in Bogotá, Colombia (2015-2017). A preliminary version was discussed within the framework of the 1st Latin American Colloquium of Skeptical Studies (2017). I thank the audience for their comments and, above all, for encouraging this kind of interdisciplinary work-less orthodox but, in my opinion, quite necessary. I also thank Carlos Cortissoz and Alfonso Correa, members of the Peiras research group, and Jorge Ornelas for their corrections and suggestions, which significantly improved this paper.

${ }^{2}$ Besides the works already cited in this article, it is worth mentioning those of Caujolle-Zaslawsky (1982), Desbordes (1982), and Stough (1984), all of which focus on the figure of Sextus Empiricus.

${ }^{3}$ Turri (2012) uses the same theoretical framework but has a different motivation. Through the taxonomy of different speech acts (linguistic, conversational, and dialectical), his article sheds light upon the assertive force of Sceptical statements and explains why it depends so intrinsically on knowledge.

${ }^{4}$ As I will argue throughout this paper, it is noteworthy that, though the Sceptical and Pyrrhonian uses of language entail more than opposition, it is the chosen and privileged feature in the Homeric reference (Il. 20.248) adapted by Diogenes Laertius. Whether between philosophical opinions or between the characters of philosophers, opposition plays a central role in my argument. Already in DL 9.71, Diogenes conceives this tool as a form to trace back a Pyrrhonian ancestor to Homer's work:

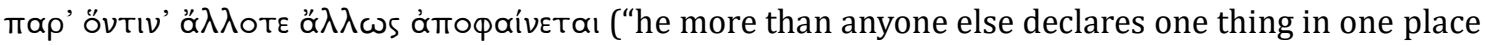
but another in another place"). For DL passages, I use the Greek edition prepared by Tiziano Dorandi (2013) and Scharffenberger and Vogt's translation (2015) with slight changes.
} 
I begin by discussing Corti's (2015) chapter because it is the most recently published study (to the best of my knowledge). In addition, though his wellgrounded work sheds some light on the matter, it still relies mainly on Sextus Empiricus. ${ }^{5}$ Sextus Empiricus resorts to procedures that are more common in philosophical discussions and to dialectical resources that focus on the theses rather than on those who hold them. It is why academic literature has mainly discussed Sextus, ${ }^{6}$ while the Laertian report has received scarce attention. However, it is perhaps worth highlighting the peculiarities of that report, precisely because of its differences with Sextus, since Laertius' report focuses on the character of the defenders more than on the defended theses, as I will show in the second part of this article.

I will divide the argument into two parts. The first one is dedicated to pointing out the specificities of Diogenes Laertius' characterisation of Pyrrhonian language. Furthermore, this part of the argument evaluates if the Dogmatic criticism affects the Sceptical procedures based on the dialectical combat and its specific linguistic register. In the second part, I will focus on another linguistic register found within Pyrrhonism, which is not philosophical (at least not according to the narrow contemporary conception of what Philosophy is). This other type of register establishes Pyrrho's attitudes as desirable, using no assertoric forms of discourse.

\section{Diogenes Laertius: from intellectualism to automaticity}

Diogenes Laertius' passage is devoted to the Sceptical use of discourse, and it closely resembles Sextus' characterisation. However, there are minor differences worth noting. A first peculiar feature is established through the comparison between Pyrrhonian language and the Homeric verses cited above

\footnotetext{
${ }^{5}$ I will also resort to these Sextan passages and the positions of the researchers mentioned, especially in the footnotes. These references will allow us to see the peculiarities of Diogenes Laertius' reconstruction of Pyrrhonism, and the major lines of research in contemporary scholarship.

${ }^{6}$ Marchand (2011) devotes his article to Sextus, barely dealing with another source: Timon of Phlius. He insists, however, that Timon tries to escape philosophical writing by taking refuge in literary discourse in order not to betray Pyrrho's legacy. From his brief suggestions I would like to highlight: "[...] Timon's verses admit a plurality of interpretations"; "The Silloi launched a new literary genre which takes its very name from the title Sillo - that attained such preeminence that, retrospectively, some ancients tried to attribute its invention to Xenophanes and even to Homer; on the contrary, his endeavour seems to achieve the adaptation of the uncompromising position of Pyrrho to philosophical debates" (p. 116); "Poetry, humour and parody are for Timon among the means by which to disseminate Pyrrho's original position [...] without committing a parricide" (p. 117). These assessments of Timon's literary work insist on the intention of maintaining Pyrrho's nonassertiveness as a guideline for the construction of his discourse and on elusiveness and interpretative plurality as the most suitable mechanism for achieving.
} 
(DL 9.73.11). ${ }^{7}$ The search for a poetic, and specifically Homeric, ancestry is commonplace in the Laertian reconstruction of many doctrines; it is a feature that may even be attributed to the self-promoting discourse of the schools. ${ }^{8}$ Therefore, what is distinctive in this passage is the characterisation of language that this presentation adds:

(T1) DL 9.73.11-6

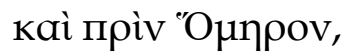

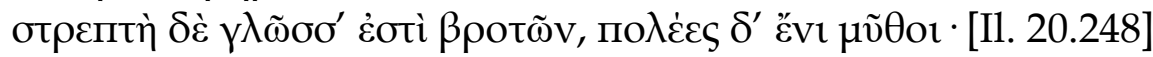

Kaì

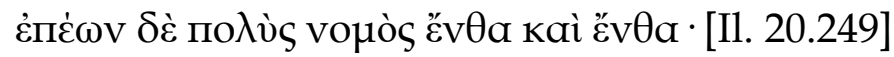

Kaì

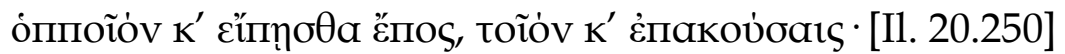

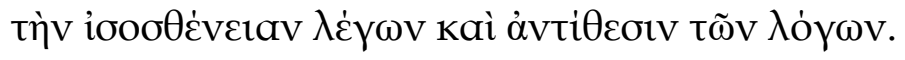

And earlier Homer said,

"The tongue of mortal men is pliant, and many are the tales on it."

(Il. 20.248)

And,

"The range for words is great here and there." (Il. 20.249)9

And,

"Whatever sort of word you might say, such you might hear." (Il. 20.250)

These quotations refer to the equal strength of statements and to the opposition of arguments.

Although the conclusion of the quoted passage is technical and framed only in the philosophical presentation of Scepticism, it is useful to remember that the Homeric verses correspond to the conversation between Achilles and Aeneas on the battlefield (Il. 20.175-259). In the Trojan warrior's words, there are two themes present on the analysis proposed by both of them, the Diogenes Laertius' passage and the work of Timon. On the one hand, the power of words can be

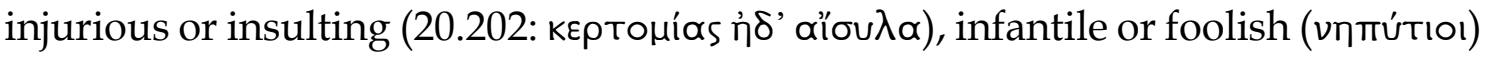

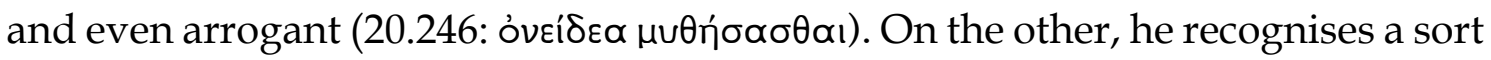
of human boasting. Regardless, Aeneas thinks that none of them counts; it is in a battle that it is revealed who is who. In this context, the above characterisation of human language appears. Hence, men's language is described as 'pliant', 'full of

\footnotetext{
7 In DL 9.71-3, Diogenes Laertius looks for some antecedents of this hairesis. He also mentions Archilochus, Euripides, Xenophanes, Zeno (of Elea), Democritus, Plato, Empedocles, and Heraclitus. However, regarding the specific uses of language, only Homer and Hippocrates are mentioned, whose

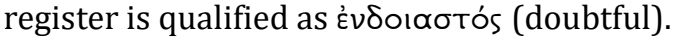

8 It happens mainly in Stoicism (cf. Cicero's ND 2.63-72).

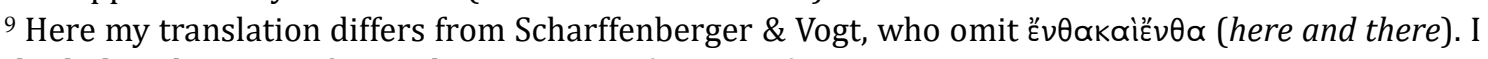

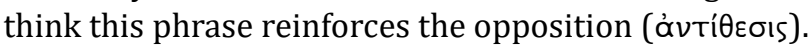


tales', and with a 'wide range for words here and there'. Moreover, language is constantly changing, even becoming contradictory, since it adapts to the purpose of each speaker.

Thus, Diogenes Laertius clarifies that Pyrrhonian language is not

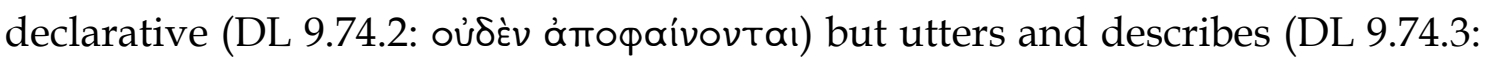

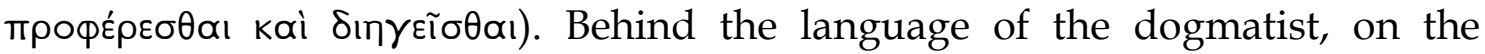
contrary, there is boasting and belief in its univocal character. To emphasise this distinction, Corti introduces Searle's concept of illocutionary force:

(...) Furthermore, in uttering this phrase, the sceptic affirms nothing but reports a feeling of his. Sextus puts forward here a double characterisation of the sceptical expressions, grounded on a double distinction. The first is the semantic distinction between phrases describing the speaker's feeling and phrases describing objects external to the speaker. The second distinction concerns the illocutionary force with which the sceptic utters his phrases: whether he affirms what he says or does something else. (Corti, 2015, pp. 127-8)

The illocutionary force of a speech act points to the various functions that a statement fulfils or can fulfil and not to the field of action in which the proposition should be interpreted. ${ }^{10}$ Although he mentions it, Corti merely distinguishes between the state of the reporter and the content of the report:

We may now put forward the salient features of the Sextan characterisation of sceptic speech acts. The sceptic's phrases have a certain meaning: they mean a proposition of the form "It appears to me now that $\mathrm{P}^{\prime \prime}$. The sceptic utters these phrases with a particular illocutionary force: he does not affirm them -manifesting a judgement he has made- but express or confess his characteristic psychological state, that of having a certain appearance, when he has it. (Corti, 2015, p.129).

\footnotetext{
${ }^{10}$ Barnes had already used this theoretical framework for Sextus Empiricus (1990, p. 2625) and so had Corti himself (2009, p. 115-25). Austin's characterisation is clear about the distinction: "[...] it might be perfectly possible, regarding an utterance, to say 'It is going to charge', to make entirely understandable 'what we were saying' in issuing the utterance, in all the senses so far distinguished, and yet not at all to have cleared up whether in issuing the utterance I was performing the act of warning or not" (Austin, 1976, p. 98). Thus, Mc Pherran (1987, p. 296, n. 18) insists that the distinction between statements is not grammatical but lies in the speaker's intention each time they are uttered: "[...] the Sceptic (unlike the Dogmatist) does not intend to affirm or deny that something is the case (...) when he intends to merely 'say something' non-assertively. It is important to realise that there are no 'languages' of assertion or non-assertion differentiated by a grammatical form; rather, the difference lies in the intent productive of the relevant speech act and the metaphysical presuppositions involved in the intention to assert something."
} 
With this distinction, Austin himself points to a rhetic act rather than to the illocutionary force of the uttered words. As a unit of speech, the rheme can be vague, void or obscure (Austin, 1962, p. 98). Corti's reformulation of Pyrrhonian speech acts clarifies, in Austin's terms, the rheme; namely, the references of utterance are not the state of things but the mental states of the individual who utters the words. As seen later, Corti does not intend to deny the assertiveness of Sceptic's discourse, but only to restrict it to the phenomenal realm. Let us contrast the following passages:

(T2) DL 9.103.1-6

To these critics [sc. The Dogmatists], Sceptics respond: Concerning those things by which we as human beings are affected, we concede

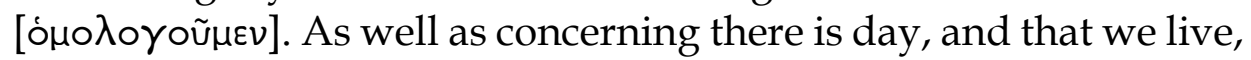
and many other things that appear to us in life, we discern

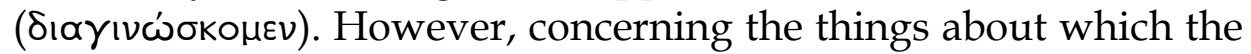
Dogmatists make strong affirmations, claiming that they have grasped them - concerning these things we suspend judgment

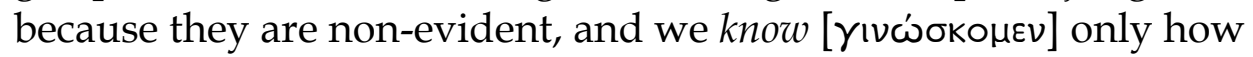
we are affected.

(T3) P. 1.200.1-12

Our attitude is similar when we say 'Everything is inapprehensible'

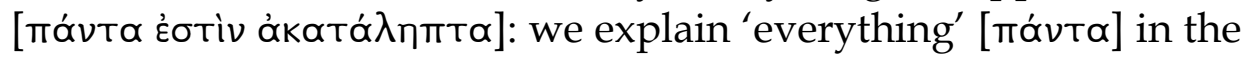
same way, and we supply 'to me' ['zhoí]. Thus, what is said is this: 'All the unclear matters investigated in a dogmatic fashion which I have inspected appear to me inapprehensible.' It is not to make an affirmation that the matters investigated by the Dogmatists are of such a nature as to be inapprehensible. Instead, it is to report our

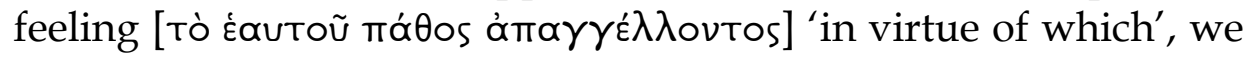
say, 'I suppose [ن́ro $\lambda \alpha \mu \beta \alpha ́ v \omega]$ that up to now I have not apprehended any of these things because of the equipollence of their opposites.' 11

In Sextan's presentation, however, we can also say that these propositions are assertoric. Such propositions are interpreted in this way by those who consider that Sceptical practice consists in falsifying certain statements by opposing others with a similar claim to truth or in producing self-refuting statements. This seems to be the case with McPherran (1987) and Spinelli (1991, p. 65), despite their warnings and precautions. In Sextus, as Corti (2015, p. 129) points out, the modalization of the report is extreme; hence, the repetitive anchoring in the subject.

\footnotetext{
${ }^{11}$ I use Annas \& Barnes translation.
} 
In Sextus' text, as in other passages in Diogenes Laertius, two verbs of

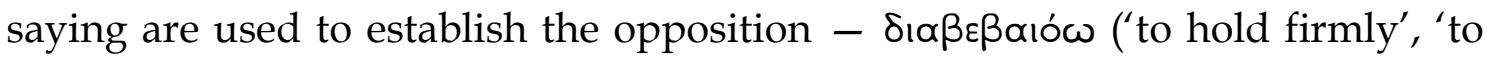

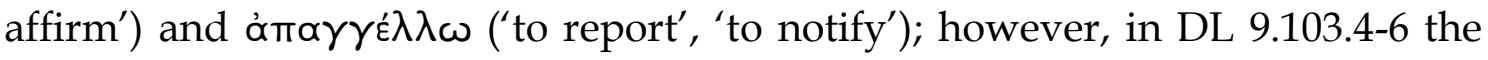

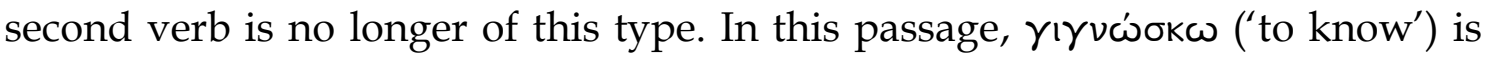
used, which implies a different commitment. In the corresponding excerpt from

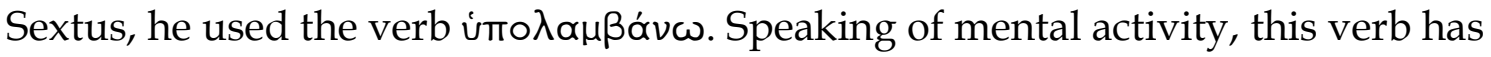
several meanings showing instability, doubt, and even passivity: to interpret, to take, to bear, to admit, to assume, to suppose, to suspect, and to cast doubt on.

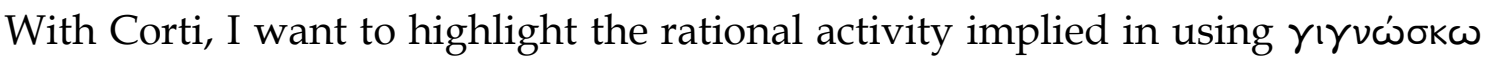
in the DL passage. So, this can mean: to know by reflection, to know by observation, to discern, to distinguish, to recognise, to be conscious of, and merely to think and judge. Thus, having reference restricted by adding émol,

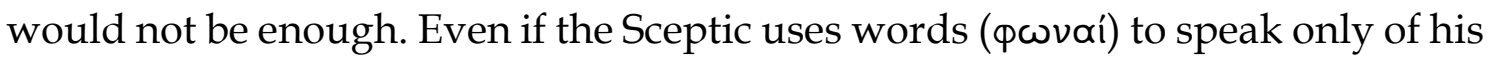
mental states, the expressions chosen do not achieve that; they always end up making him commit to some truth.

Furthermore, it is also possible that the charge of performative contradiction transcends the domain of discourse. The problem does not rest on a sort of Dogmatic misunderstanding of other uses of language, like the example about mentioning the place (DL 9.77.3-4) seems to suggest; neither on Sceptics not choosing their vocabulary well. Dogmatics believe that the Sceptical practice of comparing one discourse to another or one reasoning to another is assertoric, even if it is circumscribed to their mental states. Corti himself suggests this reading (2015, pp. 140-3), supporting it with another of the particularities in Diogenes Laertius' presentation. Examine, for example:

\section{(T4) DL 7.77.7-9}

[...] however, things appear to be, they are not that way by nature, but they only seem to be. They said that they investigate not their thoughts, since what one thinks is evident to oneself [o" tı yà vовĩTa $\delta \tilde{n} \lambda \circ \nu]$, but what they access by the senses.

In both passages (T2 and T4), I have highlighted those verbs that would not be expected in Sceptic discourse, because of their cognitive load and their ontological commitments. Corti justifies the use of these verbs by insisting on the distinction between non-evident external objects and the individual's feelings or psychological states. Besides, he clarifies that for talking about external objects; it is necessary to have concepts and beliefs about them, i.e. a robust cognitive apparatus also committed to truth. Corti argues that these assumptions are unnecessary for knowledge that is based on impressions without inferences or other mediated mental states. 
Corti's interpretation is strongly speculative and could even be considered contrary to the spirit of Scepticism, insofar as it attributes knowledge to the subject, even if it is non-inferential. ${ }^{12}$ However, Corti's deflationism makes knowledge possible. This knowledge lets the Sceptic affirm that he agrees

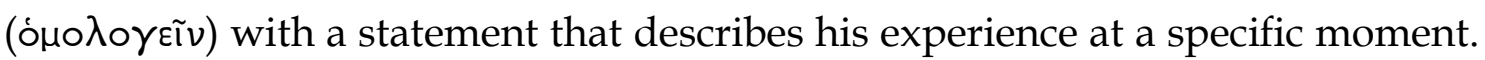
The domain of discourse and the domain of perception are circumscribed in such a way that the knowledge obtained is nothing more than a form of passivity similar in substance to any other type of perception. Corti supports his conclusion with Vendler's analysis of language. Vendler (1967, chapters 1 and 4), following Austin's analysis of ordinary language, posits a difference between propositional attitudes and factive stative attitudes. The latter are necessary and automatically true since they do not imply cognitive processes to which error or falsity can apply. Neither are they attitudes towards a judgment, expressed in the subordinate clause that is characteristic of propositional contexts. One of the essential characteristics of these factive stative attitudes is that they are not semantically analysable in terms of other more basic mental states such as perceptions. This feature allows Corti to impute passivity of the Pyrrhonian states including the state of knowledge. In that sense, knowledge is a state, not a process, such as Vendler seeks to defend based on his semantic analysis.

In this sense, it can be possible to attribute automaticity to these states. The report of this specific cognitive state happens almost as a reflex action. This kind of behaviour is innate and passive and can be part of a more complex reaction to the environment. Being innate, this behaviour can be attributed to all member of a species as part of their natural baggage, without learning, processes or prior experiences. So it is predictable and still involuntary. Sometimes, on unusual occasions, these reactions are out of place. They could be motivated by a confused perception or even an inexistent one ${ }^{13}$.

With all these restrictions in mind, this specific sceptical language would not be an intellectual but rather an everyday language, free of metaphysical speculation and judgment; the kind of discourse that allows the Sceptic, without

\footnotetext{
${ }^{12}$ However, he is not the only interpreter who attempts to describe the mental life of the Sceptic, to which our philosophically (and dogmatically) construed assumptions cannot be attributed. To explain Sextus, Vogt (1998), for example, opts for a less anachronistic framework, closer to ancient Scepticism. She tends to attribute to Sceptic a weak assent, as it is understood by the Stoics. Here 'weak' likely means: automatic, not very reflective, not granting security, and motivated exclusively by the imminence of perceptions. Both interpreters suppose that the most dogmatic feature of knowledge is systematicity, on which its inferential operation is based. Hence, they can attribute some form of cognitive apprehension to Scepticism, as long as it does not imply inferences.

${ }^{13}$ Among biologists, it is well known the case of egg retrieval by water birds. Many of them push their eggs into the nest in a complex set of movements aimed at preserving their offspring. According to the researchers, these birds repeat the movements sometimes even if the egg removed from the nest is gone or in front of some egg-shaped objects. (PREVETT, 1973, 202).
} 
philosophical arrogance, to act day by day. ${ }^{14}$ However, this use of language does not allow him to carry out his philosophical work. Pyrrho and his disciples renounce the sort of arrogance that makes it possible to trust reason, but they do not abandon reason or philosophy. They recognise that only reason can be opposed to reason, so it is an operation of the reason that can lead the Sceptic to imperturbability.

Consequently, Pyrrhonian language must be able to fulfil both tasks: on the one hand, it must dismantle the ambitions of reason and, on the other, it must promote Sceptical choice. Corti adequately explains this first task in his reconstruction of Sextus' passages (2009) and Diogenes Laertius' (2015). Corti

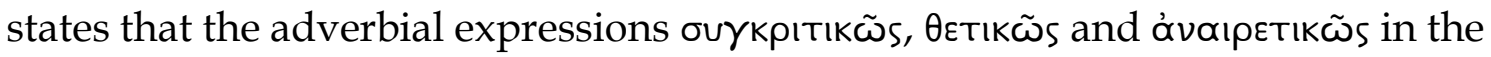

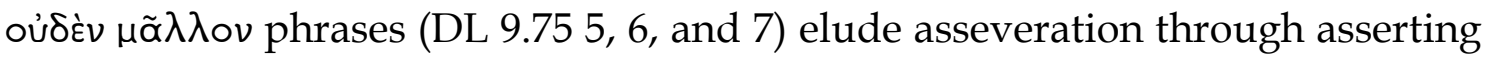
one phrase simultaneously, comparatively or negatively with its opposite. According to Corti's analysis, Sceptical expressions have the logical property of

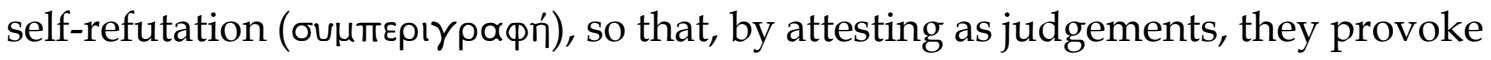
the disengagement they seek. ${ }^{15}$

So Pyrrhonian language, like that of mortals, is pliant and has a broad spectrum of application to judgments and mental processes but also feelings and perception. We still have to determine other functions beyond those that the philosophical range offers. In what follows, I want to explore how a particular lifestyle can be promoted without using assertoric discourse and without boasting of excessive confidence in the power of reasoning ${ }^{16}$.

\footnotetext{
${ }^{14}$ Spinelli (1991) also attempts to examine the legitimacy of Sceptical expressions and offers a general outline of the discourse that seems to be behind the vagueness of the adverbs used by Sextus $(P$.

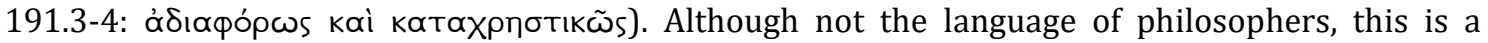
technical language, not ordinary, whose purpose is to aim at the speaker's mental states, i.e. at the phenomenal, and not at objects or events. It gains meaning conventionally and is diachronically and diatopically changed (M. 1.82) depending on the linguistic framework in which they express themselves. All expressions in it have the same value so that Sceptical voices can be overridden by other expressions. Despite its precision, this language is inaccurate, not dogmatic, without claims to truth and therefore, according to Spinelli, pre-philosophical (p. 63); although perhaps we should rather say "post-philosophical" since it reaches this characterisation after a deep understanding and awareness of its operation.

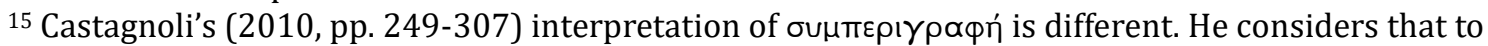
utter comparatively, positively or negatively, should not be understood as self-refutation, because far from accepting the dogmatic position, as McPherran (1987, p. 294) believes - the Sceptic intends to answer with a much more refined dialectical tool that protects him from that accusation (p. 252).

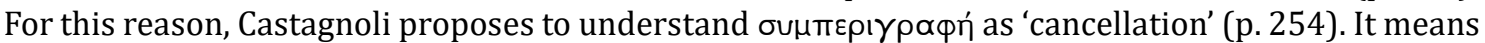
that the opinions in dispute are not falsified, and its assertive weight does not cancel them simultaneously. Consequently, Castagnoli denies the dogmatic interpretation (assertive as Corti's) and favours a report of the subject's affections that merely puts in parentheses (p. 268) the opinions

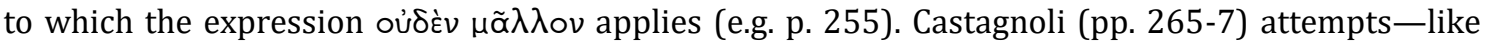
Corti, Spinelli, and Vogt-to provide the Sceptic with logical mechanisms that, without relying on the assertion, could lead to the suspension of judgment and tranquillity.

${ }^{16}$ It is symptomatic of a reading of Scepticism always to demand a justification of the ethical implications that derive from their methods of metaphysical or epistemic questioning. It is so because in later philosophy, the epistemic interpretation of Scepticism has prevailed. Except for the Academics - who are precisely the primary source of modern and contemporary scepticism -, all ancient Sceptics
} 


\section{Poetic resources: the catalogue as report and history}

Timon (325-235 BC) ${ }^{17}$ lived and wrote before all these criticisms. For this reason, his sort of writing cannot be interpreted as a response to Dogmatic criticism or an alternative to the challenge proposed. However, we know that Pyrrho himself did not write. Far from being a pupil with a doctrine of his own, ${ }^{18}$ Timon only wants to present Pyrrho's position without betraying him. In the light of Brunschwig's analysis (1994a, pp. 195-6) of Aristocles' passage, for example, one can refute this claim and consider that many of the theses traditionally attributed to Pyrrho are Timon's. It is even possible to maintain that Timon's purpose is to respect the Sceptical choice. ${ }^{19}$ Hence, I would like to argue he favours a literary register rather than a dialectical or purgative one in the line attributed to the new Pyrrhonians.

From Diogenes Laertius, we also know that Timon was a prolific writer, of both philosophical treatises - On nature and On the senses (9.105) - and literary works. Despite minimal remains of the former, ancient and current commentators insist on attributing to him an understanding of the different kinds of propositions and their operation in scientific demonstrations and discoveries. Based on the testimony of Sextus' that alludes to the roles of hypotheses in mathematical investigations (M. 3.1), the discourse of Timon is likened to the Aristotelian argumentation in Metaphysics $\Gamma$ and the Analytics. Therefore, it does not seem possible to suppose that Timon's forms of expression are clumsy attempts at a discourse like the sextan language discussed previously. These treaties could belong to the time when he was Stilpo's pupil. Therefore, perhaps not even to his time as a Pyrrhonian (LONG, 2006, p. 94). Once Timon chooses Pyrrhonian Scepticism, his rhetic register changes, and he adopts a literary style. However, before specifying Timon's preferred style and its peculiar features as

considered their attitude as a set of ideas answering the question about the best life we can live (e.g. SE P.1.12 and Cic. Fin. 4.43).

17 Timon is recognized as almost contemporary with Pyrrho and in the strict sense the only one who is undoubtedly his disciple. According to Diogenes Laertius' lists, he wrote over sixty works, which

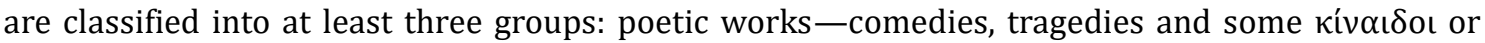
obscene poems; philosophical works-On the senses and perhaps On nature; and finally the works dedicated to praise Pyrrho's way of life. It links him to Stilpo the Megarian (DL 9.109), from whom he adopted a favourable attitude towards Eleatism (cf. fragment 45D). About his life, we know that he was a dancer before he became a philosopher and that he suspended his training with Stilpo to return to Phlius and marry. After his time with Pyrrho, he lived in Athens, earning a living by teaching philosophy.

${ }^{18}$ It is common in secondary literature (cf. Marchand, 2011, p. 115) to relate Timon to Plato, since Socrates, like Pyrrho, did not write. However, perhaps we should rather link him to Xenophon, whose literary accounts addresses in the form of expository and advertising writing that, while defending some philosophical choice, does not intend to present or defend a substantive position.

${ }^{19}$ Concerning the Indalmoi (1994b, p. 219), Brunschwig attributes to Timon this purpose. 
opposed to other equally philosophical poetic genres, it is necessary to clarify the motives of his choice.

What is Timon's purpose exactly? According to Decleva Caizzi (1986, p.176), it is to introduce Pyrrho's lifestyle to the disputes between Hellenistic philosophical schools. Chiesara (2007) expands this claim, placing Timon's attempt in the context of Athens, in the fourth and third centuries B.C. It was a city full of philosophical schools and disputes about alternative models of life. Chiesara understands Timon's need to position himself among his contemporaries as a sign of philosophy's professionalisation, a challenge that Timon assumes in his Silloi, his most representative work. He constructs a history of philosophy ${ }^{20}$ and a presentation of the controversy among past and present philosophical schools in a non-combative and non-argumentative style.

Clayman has already pointed out that there are two epic procedures used by Timon: the catalogue 21 (2009, p. 79) and the scenes about troop reviews, i.e. the famous teichoscopia. However, despite Clayman's detailed description, he does not attempt an interpretation. He and others have pointed out that in Hellenistic contexts, the reference to Homer as an ideological or literary predecessor is inescapable. The mention of the stoic Cleanthes has the same purpose. Homer, Hesiod and Heraclitus are illustrious authors whom every school wants to claim as predecessors.

From the literary point of view, in Timon's style, there is evidence of one type of Homerism, similar to Pseudo-Apollodorus' Bibliotheca (2nd century BC) and the Batrachomyomachia (2nd-1st century BC).

Although both poems are posterior, they paradigmatically represent a literary construction incipient in Timon. The latter, for example, is a mixture of genres of a parodic sort, precisely because it uses themes or plots of a poetic model in the linguistic register of another model. Using the theme and message of Aesop's fable of the frog and the mouse, the Alexandrian author narrates a conflict and its development in the style of the heroic battles in Homeric verse and with the same use of scenes. Likewise, the Bibliotheca is a compendium of mythological and heroic stories, presented in an encyclopaedic format which did not belong to any of the previous philosophical genres; because of these features, this work became a reference for later authors.

Timon uses epic as the realm of deeds, of actions rather than words. That agonistic spirit allows him to portray Pyrrho as a hero who prevails because of

${ }^{20}$ Based on what remains of his Silloi, Timon dealt with a vast repertoire of philosophers, and he was interested in presenting their "doctrines" in the same narrative style that biographers will adopt now, among these Diogenes Laertius.

${ }^{21}$ The catalogue is an artefact of composition very usual in Ancient Epic that is mainly used to provide information about the past, trace lineages and origins, and/or preserve the memory of events and heroes with no written record. 
his deeds and not because of his theories. Aeneas anticipated this attitude in the Iliad passage on the indeterminacy of human language. Whatever human purposes are, words pass, and men can only judge from their deeds; dogmas pass, but forms of life remain. In the same parodic tone, Timon takes up the subject and purpose of the agonistic works of contemporary philosophers and pours them into the Homeric cast of champion battles, in which heroes are presented very briefly using an epithet. He either identifies them within a lineage or attributes to them a quality that distinguishes them from others. Thus, he offers a comprehensive and encyclopaedic view of the history of philosophy up to its time. ${ }^{22}$

Concretely, the mentioned scenes are instrumental in virtue of their scheme and purposes. They constitute a presentation of characters or objects and circumstances, both the teichoscopia and the epipoleseis can be considered catalogues. I am interested in reducing these narrative forms to the catalogue because I hope to defend that this rhetorical instrument offers Timon a way of reporting and making history, which is very close to the aspirations of the Sceptical discourse.

\subsection{Epic catalogues and philosophical historiography}

Interpreters of the Silloi understand the work as a catalogue in the style of those we find Homeric epic. Clayman's interpretation is supported by the coincidences between the Homeric verses ${ }^{23}$ and those used by Timon to introduce his list of philosophers:

(T5) DL 9.112.4

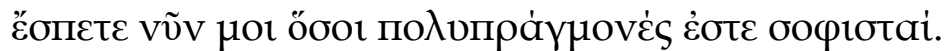

Tell me now, all of you who are sophists, curious and prying.

(T6) Il. 2.484

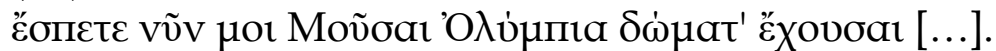

Tell me now, Muses who have Olympian dwellings [...].

Besides the formula that topically introduces this kind of scene, it is worth highlighting the changes introduced there: the Sophists replaces the Muses, and

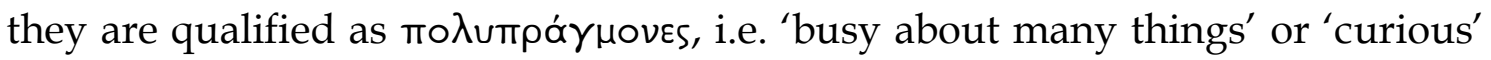

\footnotetext{
22 This awareness of the power of epic rhetorical instruments is even attributed to the Homeric poets themselves in the most recent studies (SAMMONS, 2010, p. 3). Given the parodic character of Timon's text, it is even more natural to assume it.

${ }^{23}$ Besides the reference to Book II of the Iliad quoted in T5, the same beginning of verse occurs in Il. 11.218 and $14.508 ; 16.112$.
} 
and 'prying', as Scharffenberger and Vogt translate. The adjective is interesting because Diogenes attributes the opposite quality to Pyrrho:

(T7) DL 9.64.11-65.5

What is more, there were many who admired the way Pyrrho kept

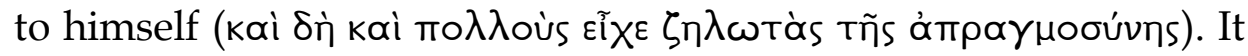
is why Timon said the following about him in the Pytho $<\ldots>$ and in his Silloi: "O old man, o Pyrrho! How, or from what inspiration, did you discover the means of casting off the servitude imposed by the empty-headed fancies of sophists? How did you loosen the bond of every deception and every effort to persuade? You had no interest in asking after these things: in pursuing what distractions

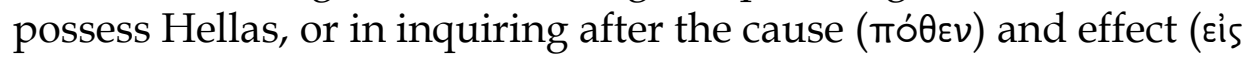
ö $\mathrm{Tl}$ ) of every single thing."

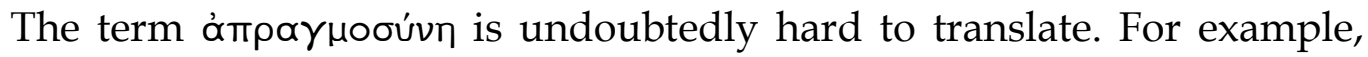
Correa and Sánchez (2013, p. 220, n. 7) choose 'tranquilidad', since they think this term positively encompasses the qualities formerly attributed to Pyrrho: indifference, detachment, etcetera. It is, in fact, the other sense of the word in the

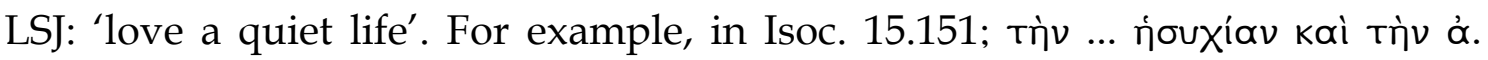

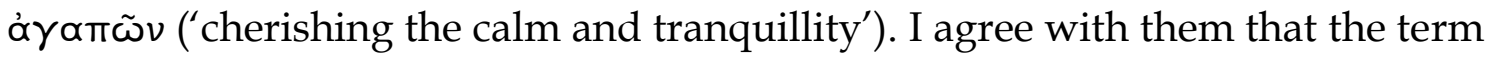
aims to characterise Pyrrho positively, and therefore I discard such meanings as 'carelessness', 'indolence', or 'laziness' 24 . However, Pyrrho's mental states are not the main topic here, but his social and political (or, more precisely, apolitical) attitudes. Therefore, I prefer Hicks' election (vol. 2, p. 479) 'abstention from affairs $^{\prime 25}$. I believe that the political context of the passage should be maintained (i.e. the consequences of his behaviour for the polis) in the translation. So in this way, it is clear the opposition that Timon himself is making between Pyrrho and

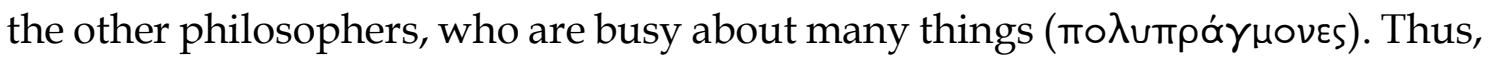
I believe that this is an instance of the first meaning in the LSJ, 'freedom from politics', of which Xenophon's Memorabilia 3.11.16 is an example: ó $\Sigma \omega$ kpótms

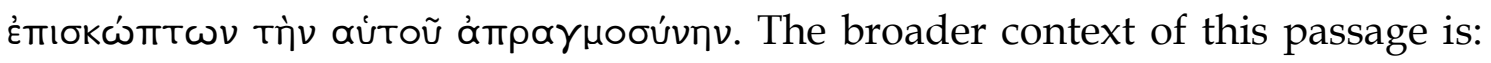
"And Socrates, joking about his own lack of busyness, said: 'But, Theodote, it is not very easy for me to find leisure for in fact many affairs both private and public deprive me of leisure.'"26

Let us return to Diogenes Laertius' passage (T7). There this trait of character is connected with an epistemic and judicial attitude, i.e. the inquiry and the absence of opinions. That trait is also connected with a lack of concern about

${ }^{24}$ The negative senses in the LSJ are: 'love of ease', 'easiness of temper', and 'inexperience.'

25 This interpretation is shared by Bredlow (2010, p. 350), 'retraimiento' (i.e. 'withdrawing') and Scharffenberger \& Vogt (2015, p. 19), 'a keeping to oneself'. García Gual (2013, p. 235), in contrast, chooses a negative translation: 'negligencia de las cosas' (i.e. 'negligence of things').

${ }^{26}$ Translated by Bonnette (1994). 
knowledge and about questions on the meaning - the direction and perhaps the end - of everything. Also as in the Silloi being a oopıotŕs is joined to the opposite

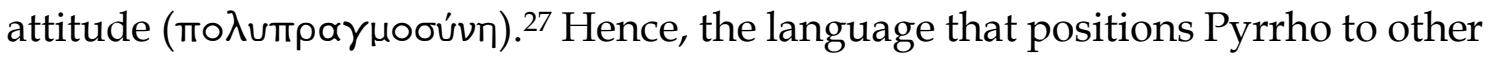
philosophers must also dispense with judgments, conceptualisations and inferences. It cannot attempt to set objectives or concrete paths.

In virtue of these aims, it is necessary to rethink the use of the catalogue. Strictly speaking, catalogues are a discrete list of items of any type organised sequentially, without an explicit relationship between them through connectors or anaphoric elements (cf. SAMMONS, 2010, pp. 7-8). This feature is present in Timon's fragments. Thus, oíos and 'íov and its variants - the usual anaphoric elements in the women's catalogue in Hesiod and Odysseu's vékvıa, for example - appear several times (oĩ os: 9, 23, 26, 27, 46). Not only I do want to insist on the formal continuity pointed out by Clayman; but I would also like to show that the aim of this list is the same. Far from parodying its procedure, it wants to use it. This kind of anaphoric connector does not have a restrictive interpretation and, rather than establishing a conceptual link between the items in the list, it introduces them. Other scenes, as I said before, can be considered a more complex catalogue, slightly more elaborated: the teichoscopia and the epipoleseis. Unlike pure catalogues, these connect the listed items among themselves, establishing links of other types: lineage, geopolitics, and social position. The first type of scene allows to visualise the combatants and to present the cast of the characters that will be in the narrative. The second one lets us harangue and review the troops and link them to certain ideals. So Clayman thinks that we must understand the scenes in the fashion of the marketplace of philosophers.

However, I would like to limit the poetic elaboration to the minimum to preserve the simplicity of the list. Not only because, as Long points out (2006, pp. 82-3), given the fragmentary state of this work, it would be very speculative to assimilate Timon's piece with other more complex narratives such as the vékuı, but because any different narrative model would involve categorisation, the establishment of successions, chronologies and organisations. ${ }^{28}$

Barney (1982, pp. 191-2) maintains that, in the Homeric and other later catalogues, including the Hellenistic and Medieval ones, the order of the lists is reversible because of metrical, not conceptual, requirements. Therefore, there is no chronological, logical, or causal subordination (i.e. the links we find in usual

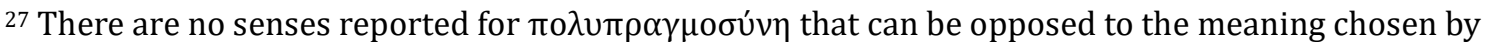
Correa \& Sánchez. Nevertheless, there are some 'psychological' senses—to label them—besides those mentioned: 'intrigue,' 'zeal,' 'indiscretion.' The most common are: 'passion for business,' 'eagerness for novelty,' etc.

${ }^{28}$ It is not surprising that Diogenes, from whom most of Timon's extant fragments come, uses it to characterize individuals with epithets and does not refer to generalizations or robust conceptualizations.
} 
narratives). In Barney's words, the catalogue is "the most actively constructing and passively recording of representations" (1982, p. 191-2). Suppose all connections are suspended, and there is no way to establish hierarchies between the elements listed. In that case, it is possible to eliminate, as Spufford (1989, pp. 5-7) does, any authority, position or dominant perspective in the text, making the readers or the audience the only ones responsible for the interpretation. Precisely, this is what happens in Book II of the Iliad, the famous catalogue of the ships, the inter-text with which Timon expressly wants to affiliate his Silloi.

We well know that this Book II is one of the most recurrent sources for the history and archaeology of the Mycenaean and Trojan world. The Schliemann arrival at Hisarlik, following the geographical route described in Book II, is famous. It is also frequently used to characterise the geopolitical organisation of that pre-Hellenic world, as well as the sources of economic wealth and global predominance. That happens thanks to the fact that the audience grasps the poet's intention with complete clarity. In Book II, the poetic voice is present and pretends to be as faithful as possible to the facts, to present the historical truth, passively, with no unnecessary interventions to transmit the message of the Muses, privileged witnesses of events:

(T8) Il. 2. 485-86

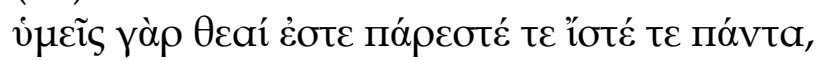

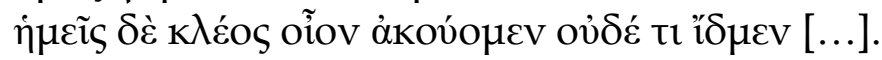

For you are goddesses and are present and you know everything, while we hear only a rumour and know nothing [...].

This characterisation should undoubtedly be familiar. There is an opposition between direct or immediate knowledge and that which comes from rumour; i.e. an opposition between supposition and reporting or writing a story, which is precisely what the Sceptics claim according to both DL 9.74.3 and Sextus Empiricus (P. 1.15). It is also familiar to both the attempt to put aside the mediation of reason and logical processes, especially inferences, in their daily operation and to reflect what is immediately presented to their senses.

The catalogue of philosophers - vaguely related to each other and barely characterised using epithets - makes it possible for Timon to create a history of philosophy from the pre-Socratics to the disputes of his time without establishing logical or conceptual relations that commit them to a specific position. It is not a minor advantage.

If Timon received philosophical training at Stilpo's Megarian school and he was familiar with Metaphysics $\Gamma$, he might have been acquainted with book A of the Metaphysics and other Aristotelian treatises. For example, according to Sánchez (2016, p. 77, my translation from Spanish and my italics): 
"[D]ialectics [i.e. discussing the opinions of predecessors] can be a tool of scientific research. [...] [T] he evidence that survives in the written works of Aristotle seems to point out that its function is necessary (though not sufficient) in the investigations to establish principles. Its work lies, above all, in the production of definitions that serve as starting points through the filtering of ancient opinions (De Anima 403a26). Dialectics manifests itself as responsible for this methodological step in the De Anima, as a provider of the elements with which divisions operate, as inferred from the systematic use of classifications that lead to the production of definitions, i.e. propositions that will work as premises and aporias."

I have emphasised the elements that make the theoretical load in Aristotle's history of his predecessors in De Anima clear, not only because Aristotle's report uses his concepts and logical operations (definition, aporias, and division), but also because that same procedure intends to be philosophically productive, i.e. it attempts to produce new knowledge. Aristotle himself says so at the beginning of the treatise, after saying that he will examine what his predecessors have said about the soul:

(T9) De Anima 403b20-2

For our study of the soul, it is necessary, while formulating the

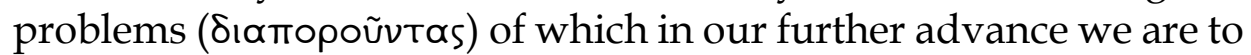
find the solutions, to call into council the views ( $\delta$ ó $\alpha$ s

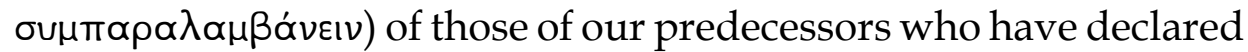
any opinion on this subject, in order that we may profit $(\lambda \alpha \dot{\alpha} \beta \omega \mu \varepsilon v)$ by whatever is sound in their suggestions and avoid their errors. ${ }^{29}$

Interpreting this Aristotelian procedure as collecting and sieving is famous: one gathers previous opinions in order to take from them what passes the test and discard what does not. Aristotle has no purgative purpose, but a manifest and genuine interest in theories for the sake of themselves. His predecessors are conceptually, progressively and almost teleologically presented. He offers information about former philosophers, though he is not interested in them but in their opinions, which are ordered in a progressive sequence leading to his discoveries. Occasionally, Aristotle even presents them as an organic and teleological development, as a natural unfolding.

Timon depicts philosophers focusing on their attitudes in ordinary life rather than their theses. Thales appears as an opportunist (23D); Pythagoras, as a trickster (5,47D); Heraclitus, as presumptuous and enigmatic (43D); Empedocles

\footnotetext{
${ }^{29}$ Translated by J.A. Smith.
} 
and Anaxagoras, as incongruent (24, 42 D); Protagoras, as cunning (5, $47 \mathrm{D})$; Prodicus, as a seller of horoscopes (18D); Socrates, as charming and a buffoon (25, 62D); Plato, as a cicada, a seducer of minds (19,30D); the Stoics, as obtuse and corrupting, but, above all, presumptuous, the worst of philosophical defects. We should also note that what Timon praises from Parmenides, Zeno, Anaxarchus, and Democritus is their attitudes, not their philosophical theses: "Parmenides' strength, magnanimous for his few opinions" (44D); "The great indomitable strength of Zeno because of his twofold language, a censor of all, and Melissus, above many vain representations and of not a few succubi" (45D); "Among the first ones I recognised Democritus, a shepherd of myths, a talker of twofold thinking" (46D); “There was known the audacious -and steadfastness wherever to strive after- fierceness canine of Anaxarchus" (58D). ${ }^{30}$

It is not that Timon does not know their theses, since we know he was acquainted with the Eleatic ideas (M. 9.197), or that his interest is not philosophical. Instead, what is at stake is not the doctrines but how they manifest themselves in life. Hence, the qualifications used are personal or ad hominem.

Many other strategies would be traceable in what survives from Timon's attempt. For example, contrary to what Clayman (2009, p. 103) Marchand (2011, p. 116) and Bett (2014) think, I consider the parallels with Lucian's Fisherman are clear. The marketplace of philosophers in the style of a fish market contributes precisely to show that philosophical schools offer themselves as food for the soul. Also, the satirical wink can be interpreted in the direction already showed, as a mechanism to position Scepticism in front of the other schools without using theses and refutation instruments.

Despite Pyrrho's withdrawing (ámpayuooúvn) and the Pyrrhonian speech that Timon tries to build, there is something to promote. Just as Corti (2015, pp. 133-4) interprets the logical strategy as a chiasmus, I believe that the same resource is implemented in the Silloi. As a poetic strategy, it is widespread in the epic. It is about building the image of a character in opposition to the characteristics attributed to another. We should remember that catalogues are not only composed by the poet but sometimes also by the characters of the piece. It is precisely the case in the Silloi since Timon is a character in his work. In these cases, that actual intention, with the pretence of objectivity, supports a less unprepared purpose; for example, the catalogue of women offered by Ulysses in his trip to the netherworld. He is undoubtedly interested in contrasting two characteristics: one that gathers all women named, who are the wives of some hero; another, which distinguishes each from the others. His list reflects what worries him about his wife. Like some women mentioned above, he hopes that she will remain faithful to his memory, fearing that, like the others, she has been

30 These translations are mine. 
unfaithful and renounced waiting for him. The readers of the Odyssey know this structure of chiasmus dominates the epic, always contrasting the house of Agamemnon with the house of Ulysses. Timon exploits the same mechanism.

Its procedures attempt rather to distinguish Pyrrho from a particular philosophical tradition, and hence Timon describes the other philosophers with characteristics contrary to those attributed to Pyrrho. He uses, for example, the

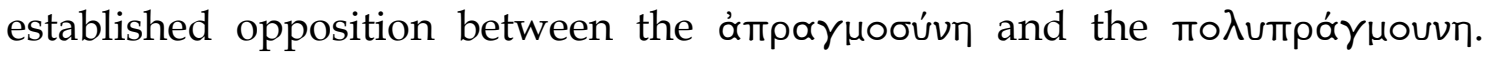
Thus, philosophers are blamed as pretentious and vain, while Pyrrho is ơ tupós (9D). This characterisation is intentional; in the first place, we assume that his writing is there to promote the choice of his teacher. Besides, his intention is evident by the vast number of neologisms preserved in the scant evidence we have, including that characterisation of Xenophanes as úmotupós.

I have used the word "language", i.e. $\gamma \lambda \tilde{\omega} \sigma \sigma \alpha$, widely to refer to the spectrum of linguistic uses that the Pyrrhonian Sceptic uses. This word encompasses much broader uses than those of philosophical discourse. The Pyrrhonian language not only talks about theories, positions, debates, and arguments; it also serves to move intuitively and tentatively in the world. This kind of language could be a vehicle for less orderly and systematic stories than historiographical ones, more enunciative than declarative, descriptive rather than categorical. In that spectrum of use and meaning, literary writings have a refreshing and therapeutic role that is worth taking advantage of.

\section{BIBLIOGRAPHY}

\section{Primary sources}

ARISTOTLE. On the Soul. Translated by J.A. Smith in The Completed Works of Aristotle Vol. 1. J. Barnes (Ed). Princeton: University Press, 1984.

$\triangle$ IOTENOY $\Sigma$ AAEPTIOY TYYPPWN KAI TIMWN. Text by Tiziano Dorandi and Translation and Commentary by Elizabeth Scharffenberger and Katja Maria Vogt, in Pyrrhonian Scepticism in Diogenes Laertius. Vogt, K (ed). Tübingen: Mohr Siebeck, p. 16-71, 2015.

DIÓGENES LAERCIO IX, 61-116: Pirrón y los pirrónicos. Traducción y comentario. Traducción de Alfonso Correa Motta y Liliana Carolina Sánchez Castro. En: Ideas y Valores, Vol. LXII, nº 151, pp. 215-238, Abril de 2013. 
DIOGENES LAERTIUS. Lives of Eminent Philosophers. Tiziano Dorandi (Edited). Cambridge Classical Texts and Commentaries. Cambridge University Press, 2013.

DIÓGENES LAERCIO. Vidas y opiniones de filósofos ilustres. Traducidas y comentadas por Luis-Andrés Bredlow. Barcelona: Editorial Lucina, 2010.

DIÓGENES LAERCIO. Vidas y opiniones de filósofos ilustres. Traducción introducción de Carlos García Gual. Madrid: Alianza, 2013.

TIMONE DI FLIUNTE. Silli. Introduzione, edizione critica, traduzione e commento. A cura di Massimo di Marco. Roma: Edizione dell' Ateneo, 1989.

XENOPHON. Memorabilia. Translated and annotated by Amy L. Bonnette. With an Introduction by Christopher Bruell. Cornell University Press, 1994.

\section{Secondary references}

AUSTIN, John L. How to do Thing with Words. The William James Lectures delivered at Harvard University in 1955. Oxford: Clarendon Press, 1976.

BARNES, Jonathan. Pyrrhonism, Belief and Causation. Observations on the Scepticism of Sextus Empiricus, in Haase, W \& Temporini, H. Aufstieg und Niedergang der Römischen Welt. Part II: Principate. Vol. 36.4, Berlin-New York, pp. 2608-2695, 1990.

BARNEY, Stephen. Chaucer's Lists. In The Wisdom of Poetry, ed. D. Benson and S. Wenzel, pp. 189-223. Kalamazoo, 1982.

BETT, Richard. Timon of Phlius, The Stanford Encyclopedia of Philosophy (Winter 2014, Edition), Edward N. Zalta (ed.) URL= https://plato.stanford.edu/cgi-bin/encyclopaedia/archinfo.cgi?entry=timonphlius, 2014. 
BRUNSCHWIG, Jacques. Once again on Eusebius on Aristocles on Timon on Pyrrho. Papers on Hellenistic Philosophy. Trans Janet Lloyd. Cambridge University Press, 1994a.

The title of Timon's Indalmoi: from Odysseus to Pyrrho. Papers on Hellenistic Philosophy. Trans Janet Lloyd. Cambridge University Press, 1994b.

CAUJOLLE-ZASLAWSKY, F. La méthode des sceptiques grecs. Revue philosophique 2, p. 371-381, 1982.

CASTAGNOLI, Lucas. Ancient Self-Refutation. The logic and history of the Self-Refutation Argument from Democritus to Augustine. Cambridge University Press, 2010.

CHIESARA, MARIA LORENZA. Historia del escepticismo griego. Madrid: Ediciones Siruela, 2007.

CLAYMAN, Dee L. Timon of Phlius Pyrrhonist into Poetry. Berlin: Walter de Gruyter, 2009.

CORTI, Lorenzo. Scepticisme et language. Paris: Vrin, 2009.

Mind and Language of the Laërtian Pyrrhonist: Diog. Laert. 9, 74-77. Pyrrhonian Skepticism in Diogenes Laertius. Vogt, K (ed). Mohr Siebeck, Tübingen, 2015.

DECLEVA CAIZZI, F. Pirroniani ed Accademici nel III Secolo A.C. Aspects de la philosophie hellénistique, Entretiens sur l'antiquité classique, tome XXXII. Vandoeuvres/ Genève, Fondation Hardt, p 147-183, 1986.

DESBORDES, F. Le langage sceptique. Notes sur le Contre les grammairiens de Sextus Empiricus. Langages 65, p. 47-74, 1982.

LIDDLE, Henry \& SCOTT, Robert (LS) A Greek- English Lexicon. Revised Supplement by H. S. Jones y R. McKenzie. Oxford: Clarendon Press, 1996. 
LONG, Anthony. A. Timon of Phlius: Pyrrhonist and Satirist. From Epicurus to Epictetus. Cambridge University Press, 2006.

MARCHAND, Stéphane. Sextus Empiricus' Style of Writing. New Essays on Ancient Pyrrhonism, 2011.

MCPHERRAN, Mark. Skeptical Homeopathy and Self-Refutation. Phronesis. Vol. 32, No 3, pp. 290-328, 1987.

PREVETT, J.P \& PREVETT, L.S. Egg Retrieval by Blue Geese. The Auk: Ornithological Advances. Vol. 90, N¹, Jan, pp. 202-204, 1973.

SAMMONS, Benjamin. The Art and Rhetoric of the Homeric Catalogue. Oxford Scholarship, 2010.

SÁNCHEZ CASTRO, Liliana C. Traditio animae: la recepción aristotélica de las teorías presocráticas del alma. Bogotá: Universidad Nacional de Colombia, 2016.

SPINELLI, Emidio. Sceptics and Language: Phonai and Lógoi in Sextus Empiricus. Historie Epistemologie Language, tome 13 Fascicule 2, p. 57-70, 1991.

SPUFFORD, Francis. The Chatto Book of Cabbages and Kings: Lists in Literature. London: Chatto \& Windus, 1989.

STOUGH, Charlotte. Sextus Empiricus on Non-assertion. Phronesis 29, p. 13764, 1984.

TURRI, J. Pyrrhonian Skepticism Meets Speech-Act Theory. International Journal for the Study of Skepticism 2, p. 83-98, 2012.

VENDLER, Zeno. Linguistics in Philosophy. Ithaca, Cornell University Press, 1967. 
VOGT, Katja. Skepsis und Lebenspraxis: Das Pyrrhonishe Leben ohne Meinungen. Alber Verlag, 1998.

Data de envio: $27 / 09 / 2020$

Data de aprovação: 29/11/2020

Data de publicação: 21/12/2020 